\begin{tabular}{|l|l|}
\hline Postprint Version & 1.0 \\
\hline Journal website & $\underline{\text { http://www.informaworld.com/smpp/content } \sim \mathrm{db}=\text { all?content }=10.1080 / 0014013}$ \\
\hline Pubmed link & $\underline{\underline{\text { http://www.ncbi.nlm.nih.gov/pubmed/20658395 }}}$ \\
\hline DOI & $10.1080 / 00140139.2010 .500402$ \\
\hline
\end{tabular}

This is a NIVEL certified Post Print, more info at http://www.nivel.eu

\title{
On-site observations of physical work demands of train conductors and service electricians in the Netherlands
}

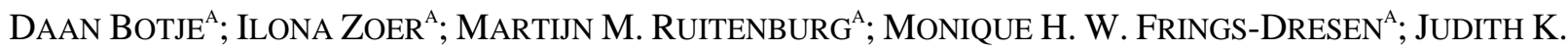 \\ SLUITER $^{\mathrm{A}}$ \\ ${ }^{a}$ Academic Medical Center, University of Amsterdam, Department: Coronel Institute of \\ Occupational Health, Amsterdam, The Netherlands
}

The objective of the present study was to assess the exposure to physical work demands of train conductors and service electricians at a railway company in the Netherlands. On-site observations were performed using the Task Recording and Analysis on Computer observation system to identify the mean duration and frequency of tasks, activities and body postures. In total, 36 train conductors and 41 service electricians were observed for a net working day of 7 h. Results showed that train conductors and service electricians climbed a flight of stairs on average 249 and 258 times, respectively, and that service electricians worked above shoulder height for $65 \mathrm{~min}$ on average. In both jobs, guidelines were exceeded, e.g. duration of standing, the number of times climbing a flight of stairs, kneeling and squatting or working in awkward postures, which are risk factors for developing musculoskeletal complaints.

Suggestions are made concerning how to reduce these risk factors.

Statement of Relevance: Understanding physical work demands is essential for recognising risk factors for musculoskeletal disorders. Since train conductors and service electricians in the Netherlands reported work-related complaints, on-site observations were performed to determine the duration and frequency of physical work demands. Risk factors were identified in both professions, providing insights concerning preventative measures.

\section{INTRODUCTION}

In the Netherlands, more than one million people travel by train every day. It is an important mode of transport for which many people work hard to provide the best service. Employees in certain occupations are operationally responsible for these services, for instance, train drivers, train conductors and service electricians. In a railway company in the Netherlands, many employees have reported to their unions about musculoskeletal complaints that might have been caused by their work and are limiting them in executing their duties.

Thus far, few published studies have reported on possible physical risk factors in train employees. Some studies have investigated fatigue or exposure to wholebody vibration in train drivers (Birlik 2009) or mental workload in train signallers or railway controllers (Pickup et al. 2005, Farrington-Darby et al. 2006, Ryan et al. 2009), but no study has focused on train conductors and service electricians. Other studies have focused on physical work demands in jobs comparable with those of service electricians. The duration and frequency of tasks, activities and body postures provide insight into the physical work demands on employees. One of these studies analysed video recordings to determine postural and physical work demands and observed that employees in an automobile assembly plant frequently perform trunk flexions, trunk rotations or laterally bend over (Punnett et al. 1991, Punnett and Wegman 
2004, Wagner et al. 2009). In addition, repetitive movements of the upper extremities occur throughout their working day. However, service electricians work underneath, next to, inside and on top of trains, which makes it difficult to compare this particular occupation with other types of assembly or maintenance work. No studies could be found that examined the (physical) work demands of train conductors.

It is important to identify what work-related factors might contribute to health complaints so that employers can adjust the tasks and activities of their employees to protect their health (e.g. Straker and Mathiassen 2009). For instance, risk behaviours for developing musculoskeletal complaints are thought to include climbing a flight of stairs, kneeling, squatting, working above shoulder height and working in awkward positions (Hughes et al. 1997, Malchaire et al. 2001, Sluiter et al. 2001, Buckle and Devereux 2002, Harkness et al. 2003a,b, van der Molen et al.

2004, Sluiter and Frings-Dresen 2007). Some of these behaviours are likely to occur during the work of train conductors and service electricians, although it is not yet clear in what amounts they might be present. Prevalence of musculoskeletal complaints in the upper extremities were found to be $41 \%$ in automobile manufacturing workers (Gold et al. 2009) and 17\% in car mechanics (Svendsen et al. 2004). The prevalence of low back pain was found to be $25 \%$ in occupations where employees work mostly in standing postures (Tissot et al. 2009). Of 103 car mechanics, almost all suffered musculoskeletal symptoms from the low back, shoulders and neck in the precedent year (Torp et al. 1996).

Therefore, the railway company and the unions requested a study to identify excessive work demands on train conductors and service electricians and to compare these with existing guidelines and previous studies. Additionally, recommendations for how to decrease the occurrence of risk factors were requested in order to reach their pension in proper health.

Namely, in Denmark it appeared that ergonomic work environments such as physically demanding jobs, kneeling and squatting and working with the hands increased the risk of disability pension (Fabriola et al.

2009). Since work demands for train conductors and service electricians were unknown, the aim of the present field study was to assess the physical work demands of train conductors and service electricians who work for a railway company in the Netherlands and to compare these with guidelines and previous studies. It was thought to be important to determine physical work demands and to relate them to guidelines in order to identify risk factors for developing musculoskeletal disorders that may limit employees in executing their work. In addition, this knowledge can also be used for preventive measures.

\section{METHODS}

\subsection{Design}

The present study employed a cross-sectional design to measure the physical work demands of train conductors and service electricians.

\subsection{Participants}

In the present study, 45 train conductors and 56 service electricians were approached on their work site to be observed while executing their work. In the Netherlands, train conductors are responsible for the safety of the passengers on the train. They make sure that the train leaves safely and on schedule and they check that the passengers have valid tickets and provide information when needed. From time to time, they have to update their administration concerning tickets sold and fines and provide updated information about possible delays of the train. Service electricians are responsible for maintenance and repair of the trains. Their shifts consist of mechanical and electrical tasks, such as changing brake blocks, checking electrical circuits and repairing the windshield liquid sprayer in the cabin.

\subsection{Measurement strategy}

Preceding the observations on the work site, explorative interviews were held with train conductors, service electricians and their supervisors in order to collect general information about the tasks, activities and body postures that could occur during work.

Based on this information, combined with on-site video recording of employees performing their tasks, a hierarchical task analysis was constructed (Appendix A). The Task Recording and Analysis on Computer (TRAC) observation system (Frings-Dresen and Kuijer 1995) was used, which provides realtime data on the duration and frequency of tasks, activities and body postures during work. Variables were described by definitions that are shown in Appendix B. 
Observations of body postures appeared to be reliable when observing large body parts and rating 308 angle intervals (Bao et al. 2009). The observers practised with the observation system on the videos, after which they compared and discussed their judgements in order to come to an acceptable agreement. The observers trained until they reached a high intraclass correlation coefficient (ICC 40.80 ).

In order to assemble a representative sample, a measurement strategy was developed that captures all apparent facets of both jobs. For train conductors, the durations and frequencies of tasks, activities and body postures depended on the train's itinerary, whether they were working during or after the rush hour, at the beginning or end of the shift, on which type of train and on a regional train or long-distance train. A regional train covers a relatively short distance and stops at all passing stations, whereas a longdistance train covers a larger distance and stops only at major stations. To be able to properly estimate the groupbased mean exposure to physical work demands, the precision is influenced by the number of observations of 30-min periods, depending on the variety of the job (Hoozemans et al. 2001). In the present study, the measurement strategy for train conductors resulted in 45 observations of train conductors working on representative itineraries encompassing all of the aforementioned conditions. Since the duration and frequency of tasks, activities and body postures depend on whether the employee is working on a regional train or a long-distance train, they were observed for $30 \mathrm{~min}$ on the former or $60 \mathrm{~min}$ on the latter. Each train conductor was observed only once.

For service electricians, the duration and frequency of activities and body postures depends on whether they are near the beginning or end of their shift and whether they are performing mechanical or electrical tasks within the eight clusters of tasks that they must perform to repair or maintain the trains. Since there was little variation in the execution of their tasks, 56 service electricians were observed for 15 min each, provided that the number of observations was sufficient (Hoozemans et al. 2001). Each service electrician was observed only once.

\subsection{Observational procedure}

After the research team informed the railroad managers about the nature of the study, the employees were informed about the possibility of being approached by observers asking them to voluntarily participate in the present study from August to October 2008. To reach the employees, announcements were placed in their business newspaper, personal hand-held computers and other communication systems.

For train conductors, the observers went to train stations at the beginning of selected itineraries in the Netherlands and approached the operating train conductor to voluntarily participate in the present study. When consent was given, conductors were instructed to execute their routine as normally as possible and to ignore the observer. The observation started almost immediately and the observer followed the train conductor at a distance of 3-4 $\mathrm{m}$ in order to observe properly without hindering the train conductor from executing his/her job. The observations mostly took place on the train, which was considered to be moving from departure till arrival at a platform of a railway station.

Service electricians were asked to voluntarily participate in the present study at their workplaces.

Each was requested to execute his work in the usual way. Shortly after a service electrician agreed to participate, the observation started. During the observation, the observer remained at a safe distance while still staying close enough to observe the service electrician properly.

\subsection{Data analysis}

The observed real-time data from the TRAC system were checked and corrected for obvious errors; for instance, by deleting extreme outliers. For each subject, the duration (min) and frequency of the activities and body postures during each task were divided by the length of the observation (min) and multiplied by the length of a natural net Dutch working day of $7 \mathrm{~h}$ without breaks. Means (SD) of duration and frequency were calculated at the group level for both train conductors and service electricians, resulting in estimations of the mean durations and frequencies of the tasks, activities and body postures that occur during a natural working day. These estimations were compared with previous studies and guidelines in order to identify possible risk factors within the activities of train conductors and service electricians. These studies and guidelines were selected if they described activities and body postures that were similar to those that occurred during the work of train conductors or service electricians. 
Botje, D., Zoer, I., Ruitenburg, M.M., Frings-Dresen, H.W., Sluiter, J.K. On-site observations of physical work demands of train conductors and service electricians in the Netherlands. Ergonomics: 2010, 53(8), 1016-1023

\section{RESULTS}

\subsection{Train conductors}

In total, 36 train conductors were observed. As can be seen in Table 1, it was estimated that, during a working day, the train conductors were standing for $177 \mathrm{~min}$.

Standing occurred mostly during the task of checking for valid tickets, resulting in approximately $32 \%$ of the entire work (data not presented in this paper).

Approximately three-quarters of the total duration of standing (134 min) occurred in a moving train, with frequent occurrences of disturbance of body balance (91 times) due to unexpected lateral movements of the train. On average, they climbed 131 flights of stairs within double-decker trains (consisting of at least five steps), namely, when checking for valid tickets (121 times) and making service rounds (10 times).

Additionally, 61 flights of stairs of at least three steps were climbed to get in and out of the trains and 57 flights of stairs of an unknown number of steps were used in train stations. Subsequently, conductors were climbing 249 flights of stairs with varied numbers of steps.

Risk factors for developing musculoskeletal complaints described in previous studies include standing for more than $2 \mathrm{~h}$ per day, climbing more than 15 flights of stairs per day (Lau et al. 2000) or climbing a flight of stairs in general more than 30 times per working day (The Netherlands Center for Occupational Diseases 2008), which are considered to be risk factors for developing musculoskeletal complaints in the knees and hips, such as osteoarthritis (Jensen 2008). While working on a moving train, the train conductor also faces risks of reduced work capacity and increased fatigue (Wertheim 1998).

Although there are varying relationships found in the literature between climbing a flight of stairs and musculoskeletal complaints, in the present study the train conductors exceeded all of these guidelines by a vast amount, resulting in an increased risk for developing musculoskeletal problems in the knees and hips.

\subsection{Service electricians}

In total, 41 service electricians were observed. As can be seen in Table 2, it was estimated that service electricians work in a standing position for 264 min per working day, where standing for more than $2 \mathrm{~h}$ per day was considered a risk factor for developing osteoarthritis in the hip (Lau et al. 2000).

Standing occurred underneath, next to and even on top of the train. Additionally, service electricians were estimated to be kneeling and squatting for $37( \pm 75)$ min, to assume positions involving neck flexion for 60 ( \pm 43 ) min, to be working with their hands above shoulder height for $65(+60)$ min and to climb a flight of stairs (consisting of at least three steps) 258 times.

Climbing a flight of stairs, as aforementioned, is considered a risk factor for knee and hip complaints (Jensen 2008). This is a serious risk factor for service electricians since they climbed a flight of stairs 258 times.

Kneeling or squatting for more than 15 min per working day is considered to be a risk factor for developing knee arthritis (de Zwart et al. 2005) and service electricians exceeded that by kneeling or squatting for $37 \mathrm{~min}$.

Working above shoulder height for more than $1 \mathrm{~h}$ per working day is considered to be a risk factor for developing shoulder complaints (de Zwart et al. 2005) and service electricians exceeded that by working above shoulder height for $65 \mathrm{~min}$. Hence, the work of service electricians involves risk factors for developing musculoskeletal problems in the knees, hips and shoulders.

\section{[TABLE 1][TABLE2]}

\section{DISCUSSION}

The objective of the present study was to assess the exposure to physical work demands of train conductors and service electricians at a railway company in the Netherlands. On-site observations showed that train conductors were estimated to climb a flight of stairs (consisting of at least three steps) approximately 249 times during a net working day of $7 \mathrm{~h}$. Service electricians were estimated to work in a standing position for more than $4 \mathrm{~h}$ per working day, assume awkward postures and perform work while kneeling or squatting. In relation to risk factors for developing musculoskeletal complaints, both types of jobs appear to exceed guidelines for the frequency or duration of climbing a flight of stairs, duration of 
Botje, D., Zoer, I., Ruitenburg, M.M., Frings-Dresen, H.W., Sluiter, J.K. On-site observations of physical work demands of train conductors and service electricians in the Netherlands. Ergonomics: 2010, 53(8), 1016-1023

standing, kneeling and squatting and working above shoulder height (Wertheim 1998, Lau et al. 2000, de Zwart et al.

2005, Jensen 2008, Peereboom and Huysmans 2002).

Since many different working circumstances were incorporated into the observations and sufficient observations were obtained in relation to variation of the activities and postures, the results are considered representative for train conductors and service electricians who work for the train company in The Netherlands. The present study was part of a larger study (Ruitenburg et al. 2009), including questionnaires and interviews on psychosocial workload (Zoer et al. 2010), physical workload and possible solutions to reduce workload. From these questionnaires, the train conductors reported recurrence of knee, hip or shoulder complaints. But causal relationships between exposure and complaints could not be made here.

The durations and frequencies of tasks, activities and body postures measured through real-time observations provided insight into the physical work demands of employees. It was shown by Hoozemans et al. (2001) that the mean duration of a task or activity could be efficiently estimated by observing 10 employees four times each for $30 \mathrm{~min}$, where the total number of observations depends on the variety of the job. After having first explored the probable sources of variation in the two professions in the present study, 36 train conductors were observed for 30- 60 min and 41 service electricians were observed for $15 \mathrm{~min}$, resulting in total observation times of approximately 1600 and $600 \mathrm{~min}$, respectively, enough time to obtain a representative estimation of the physical work demands.

In the present study, train conductors and service electricians were estimated to climb a flight of stairs (consisting of three steps or more) on average 249 and 258 times a day, respectively. These outcomes lead to the expectation that climbing a flight of stairs is a risk factor for developing musculoskeletal complaints for these workers because climbing a flight of stairs more than 30 times per working day is considered a risk factor for developing knee complaints according to Jensen (2008) and the Netherlands Center for Occupational Diseases (2008). Since the train conductors climbed a flight of stairs frequently within the train (131 times), a possible solution is to eliminate these stairs from the train; hence, using single-deck trains only. The train conductors could also work in pairs so that each checks either the lower or the upper deck, resulting in a 50\% decrement in stair climbing in the train for each conductor. In the train stations, the stairs could be replaced by escalators to reduce the amount of stair climbing necessary in stations. During the task of checking for valid tickets, climbing a flight of stairs occurred 121 times. Therefore, another solution could be to develop a new procedure for checking passengers' tickets. This could be done by checking passengers for valid tickets at the train station before they board the train, resulting in a vast reduction in stair climbing for the conductors. If this solution were implemented, train conductors could use their spare time to provide further assistance and information to passengers on the train.

The work of service electricians appears to contain several risk factors for developing musculoskeletal complaints. Reduction of the observed risk factors would involve preventing the service electricians from working in a standing position for more than $4 \mathrm{~h}$ per day, working in an awkward posture and climbing a flight of stairs. This could be achieved by making adjustments to the workplace, such as by providing a stool to limit the duration of standing. Working above shoulder height and climbing a flight of stairs could be limited by providing floors that can be elevated. Since work organisation was shown to affect physical dimensions of work (Silverstein et al. 2008), alterations in work organisation could be made to reduce physical demands. On an individual level, the employees should alternate between physically demanding and less demanding tasks instead of engaging in only one demanding task for a longer period of time. A detailed analysis of workstations should provide information as to which tasks should be performed less frequently in order to decrease the physical load.

More research is needed to determine the absolute physical work demands that occur during the work of train conductors and service electricians, for instance, by combining observational data with electromyographic data or energetic expenditure. In order to be able to reliably determine what interventions could be implemented and evaluated, future studies should focus on combining observations and in-depth interviews with the same subjects. 
Botje, D., Zoer, I., Ruitenburg, M.M., Frings-Dresen, H.W., Sluiter, J.K. On-site observations of physical work demands of train conductors and service electricians in the Netherlands. Ergonomics: 2010, 53(8), 1016-1023

\section{RECOMMENDATIONS}

Train conductors are advised to decrease their stair climbing. They could work in pairs so that each checks either the lower or the upper deck, resulting in a 50\% decrement in stair climbing in the train for each conductor, or by working on single-deck trains and by using escalators where possible. Service electricians should rotate between tasks in order to decrease the duration of physically demanding tasks. Finally, elevated floors could limit the duration of working above shoulder height and the frequency of climbing a flight of stairs. Prospective studies could be conducted to determine the direction of the relationship between exposures and musculoskeletal disorders. In addition, intervention studies examining the effectiveness of interventions reducing physical work demands should be conducted.

\section{ACKNOWLEDGEMENTS}

The authors would like to thank all of the employees who agreed to participate in the present study. We also thank the committee of employees and employers for their assistance, as well as Lucinda de Graaf and Steven Visser, who assisted with the observations.

\section{REFERENCES}

Bao, S., et al., 2009. Interrater reliability of posture observations. Human Factors, 51 (3), 292-309.

Birlik, G., 2009. Occupational exposure to whole body vibration-train drivers. Industrial Health, 47 (1), 5-10.

Buckle, P.W. and Devereux, J.J., 2002. The nature of workrelated neck and upper limb musculoskeletal disorders.

Applied Ergonomics, 33, 207-217.

de Zwart, B.C.H., et al., 2005. Leidraad aanstellingskeuring.

Handelen van de arbodienst en de keurend arts bij een aanstellingskeuring. Den Haag, Ministerie van

Sociale Zaken en Werkgelegenheid. Voorjaar, 1-132.

Fabriola, M., et al., 2009. The impact of ergonomic work environments on the risk of disability

pension: Prospective results from DWECS/DREAM. Ergonomics, 52 (11), 1419-1422.

Farrington-Darby, T., et al., 2006. A naturalistic study of railway controllers. Ergonomics, 49, 1370-1394.

Frings-Dresen, M.H.W. and Kuijer, P.P.F.M., 1995. The TRAC-system: An observation method for analysing work demands at the work place. Safety Science, 21, 163-165.

Gold, J.E., et al., 2009. Specific and non-specific upper extremity musculoskeletal disorder syndromes in automobile manufacturing workers. American Journal of Industrial Medicine, 52, 124-132.

Harkness, E.F., et al., 2003a. Mechanical and psychosocial factors predict net onset shoulder pain: a prospective cohort study of newly employed workers. Occupational and Environmental Medicine, 60, 850-857.

Harkness, E.F., et al., 2003b. Risk factors for new-onset low back pain amongst cohorts of newly employed workers.

Rheumatology, 42, 959-968.

Hoozemans, M.J.M., et al., 2001. Group-based measurement strategies in exposure assessment explored

by bootstrapping. Scandinavian Journal of Work, Environment \& Health, 27 (2), 125-132.

Hughes, R.E., Silverstein, B.A., and Evanoff, B.A., 1997.

Risk factors for work-related musculoskeletal disorders in an aluminum smelter. American Journal of Industrial Medicine, 32, 66-75.

Jensen, L.K., 2008. Knee osteoarthritis: influence of work involving heavy lifting, kneeling, climbing stairs or ladders, or kneeling/squatting combined with heavy lifting.

Occupational and Environmental Medicine, 65 (2), 72-89.

Lau, E.C., et al., 2000. Factors associated with osteoarthritis of the hip and knee in Hong Kong Chinese: obesity, joint injury, and occupational activities. American Journal of Epidemiology, 152 (9), 855-862.

Malchaire, J., Cock, N., and Vergracht, S., 2001. Review of the factors associated with musculoskeletal problems in epidemiological studies. International Archives of Occupational and Environmental Health, 74, 79-90.

Netherlands Center for Occupational Diseases, 2008.

Occupational diseases [online]. Available from: www.beroepsziekten.nl [Accessed 27 May 2010].

Peereboom, K.J. and Huysmans, M.A., 2002. Handboek Fysieke Belasting: een complete methode voor het inventariseren en oplossen van knelpunten, $3^{\mathrm{e}}$ herziene druk. Den Haag: Sdu uitgevers.

Pickup, L., et al., 2005. Fundamental examination of mental workload in the rail industry. Theoretical Issues in Ergonomics Science, 6 (6), 463-482.

Punnett, L. and Wegman, D.H., 2004. Work-related musculoskeletal disorders: the epidemiologic evidence and the debate. Journal of Electromyography and Kinesiology, 14, 13-23.

Punnett, L., et al., 1991. Back disorders and non-neutral trunk postures of automobile assembly workers. 
Botje, D., Zoer, I., Ruitenburg, M.M., Frings-Dresen, H.W., Sluiter, J.K. On-site observations of physical work demands of train conductors and service electricians in the Netherlands. Ergonomics: 2010, 53(8), 1016-1023

Scandinavian Journal of Work, Environment \& Health, 17 (5), 337-346.

Ruitenburg, M.M., et al., 2009. Werkbelasting servicemedewerkers, machinisten, conducteurs en monteurs bij NS: stand van zaken en mogelijke oplossingen [Workload for service employees, train drivers, train conductors, and service electricians at the Netherlands railway company: current situation and possible solutions].Report number 08-07. Amsterdam: Coronel Institute of Occupational Health.

Ryan, B., et al., 2009. Attitudes and opinions of railway signaller and related staff, using the Rail Ergonomics Questionnaire (REQUEST). Applied Ergonomics, 40 (2), 230-238.

Silverstein, B.A., et al., 2008. Rotator cuff syndrome: personal, work-related psychosocial and physical load factors. Journal of Occupational Medicine, 50, 1062-1076.

Sluiter, J.K. and Frings-Dresen, M.H.W., 2007. What do we know about ageing at work? Evidence-based fitness for duty and health in fire-fighters. Ergonomics, 50 (11), 1897-1913.

Sluiter, J.K., Rest, K.M., and Frings-Dresen, M.H.W., 2001.

Criteria document for evaluating the work-relatedness of upper-extremity musculoskeletal disorders.

Scandinavian Journal of Work, Environment and Health, 27 (1), 1-102.

Straker, L. and Mathiassen, S.E., 2009. Increased physical work loads in modern work - a necessity for better health and performance? Ergonomics, 52 (10), 1215-1225.

Svendsen, S.W., et al., 2004. Work related shoulder disorders: quantitative exposure-response relations with reference to arm posture. Occupational and Environmental Medicine, 61, 844-853.

Tissot, F., Messing, K., and Stock, S., 2009. Studying the relationship between low back pain and working postures among those who stand and those who sit most of the working day. Ergonomics, 52 (11), 1402- 1418.

Torp, S., Riise, T., and Moen, B.E., 1996. Work-related musculoskeletal symptoms among car mechanics: a descriptive study. Occupational Medicine (London), 46 (6), 407-413.

van der Molen, H.F., et al., 2004. Efficacy of adjusting working height and mechanizing of transport on physical work demands and local discomfort in construction work. Ergonomics, 47 (7), 772-783.

Wagner, D.W., Kirschweng, R.L., and Reed, M.P., 2009.

Foot motions in manual material handling transfer tasks: A taxonomy and data from an automotive assembly plant. Ergonomics, 52 (3), 362-383.

Wertheim, A.H., 1998. Working in a moving environment.

Ergonomics, 41 (12), 1845-1858.

Zoer, I., et al., 2010. Age related associations between psychological workload and mental health complaints.

Submitted.

\section{[APPENDIX A]}

\section{[APPENDIX B]}

\section{TABLES}

Table 1. Mean duration and frequency of activities during a working day for train conductors $(\mathrm{n}=36)$.

\begin{tabular}{llrr}
\hline & \multicolumn{1}{c}{ Variable } & Duration (min) & Frequency \\
\hline Activity & Climbing a flight of stairs & $8(6.4)$ & $249(99.7)$ \\
& Sitting & $110(70.1)$ & NA \\
& Standing & $177(78.4)$ & NA \\
& Walking & $42(18.4)$ & NA \\
& Opening a door & NA & $258(110.7)$ \\
Body posture & Checking a passenger's ticket & NA & $1205(462.5)$ \\
& Cervical flexion & $50(38.3)$ & $1222(461.3)$ \\
& Cervical rotation & $21(14.2)$ & $159(65.2)$ \\
Objects & Lumbar flexion & $4(2.7)$ & $63(56.6)$ \\
& Lumbar rotation & $9(16.1)$ & $1154(469.0)$ \\
Exception & Reaching & $8(7.7)$ & $78(27.5)$ \\
& Carrying a bag & $7(5.6)$ & NA \\
& Disturbance of balance & NA & $137(69.1)$ \\
& Aggression* & NA & $3(0)$ \\
& Using hand-held computer & $16(10.0)$ & NA \\
& Obstruction & $3(0.7)$ & $78(105.7)$ \\
\hline
\end{tabular}

$\mathrm{NA}=$ not applicable

${ }^{*} \mathrm{n}=2$ train conductors who encountered aggression during observations.

Note: Values are mean $( \pm \mathrm{SD})$ of duration and frequency. 
Botje, D., Zoer, I., Ruitenburg, M.M., Frings-Dresen, H.W., Sluiter, J.K. On-site observations of physical work demands of train conductors and service electricians in the Netherlands. Ergonomics: 2010, 53(8), 1016-1023

Table 2. Mean duration and frequency of activities during a working day for service electricians $(\mathrm{n}=41)$.

\begin{tabular}{llrr}
\hline & \multicolumn{1}{c}{ Variable } & Duration (min) & Frequency \\
\hline Activity & Climbing a flight of stairs & $10(11.6)$ & $258(250.7)$ \\
& Standing & $264(98.5)$ & NA \\
& Sitting & $36(69.8)$ & NA \\
Walking & $69(58.0)$ & NA \\
& Climbing/scrambling & $1(1.4)$ & NA \\
Kneeling/squatting & $37(75.2)$ & NA \\
& Changing brake blocks & $10(30.8)$ & NA \\
Cervical flexion & $60(42.7)$ & $642(419.7)$ \\
& Cervical rotation & $30(22.5)$ & $542(403.3)$ \\
& Lumbar flexion & $32(22.2)$ & $490(338.6)$ \\
& Lumbar rotation & $3(2.5)$ & $61(36.0)$ \\
Asymmetric posture & $25(30.9)$ & $217(240.1)$ \\
Abjects & Beove shoulder height & $65(60.3)$ & NA \\
& Below hip height & $17(17.6)$ & NA \\
& Lifting a light object $(<5 \mathrm{~kg})$ & $11(10.5)$ & $1499(1891.8)$ \\
Exception & Lifting a heavy object $(\geq 5 \mathrm{~kg})$ & $18(20.8)$ & $163(188.1)$ \\
& Precision work & $172(90.2)$ & NA \\
& Rubbing/grating & $41(40.3)$ & NA \\
& Picking up/putting down & $7(6.0)$ & $129(85.5)$ \\
& Pushing/pulling & $15(21.7)$ & NA \\
& Reaching & $8(12.1)$ & $168(164.4)$ \\
\hline
\end{tabular}

$\mathrm{NA}=$ not applicable.

Note: Values are mean $( \pm \mathrm{SD})$ of duration and frequency.

Appendix A: Hierarchical task analysis - variables of interest.

\begin{tabular}{|c|c|c|}
\hline & Train conductors & Service electricians \\
\hline \multirow[t]{5}{*}{ Task } & Departing the train & Mechanical \\
\hline & Service round & Electrical \\
\hline & Checking for & \\
\hline & Administration & \\
\hline & Between tasks & \\
\hline \multirow[t]{8}{*}{ Activity } & Climbing a flight & Climbing a flight \\
\hline & of stairs & of stairs \\
\hline & Standing & Standing \\
\hline & Sitting & Sitting \\
\hline & Walking & Walking \\
\hline & Opening a door & Climbing/scrambling \\
\hline & $\begin{array}{l}\text { Checking a } \\
\text { passenger's }\end{array}$ & Kneeling/squatting \\
\hline & & Changing brake \\
\hline \multirow[t]{6}{*}{ Body posture } & $\begin{array}{l}\text { Cervical flexion } \\
\left(>20^{\circ}\right)\end{array}$ & $\begin{array}{l}\text { Cervical flexion } \\
\left(>45^{\circ}\right)\end{array}$ \\
\hline & Cervical rotation & Cervical rotation \\
\hline & $\left(>45^{\circ}\right)$ & $\left(>45^{\circ}\right)$ \\
\hline & $\begin{array}{l}\text { Lumbar flexion } \\
\left(>45^{\circ}\right)\end{array}$ & $\begin{array}{l}\text { Lumbar flexion } \\
\left(>45^{\circ}\right)\end{array}$ \\
\hline & Lumbar rotation & Lumbar rotation \\
\hline & $\left(>20^{\circ}\right)$ & $\left(>45^{\circ}\right)$ \\
\hline \multirow[t]{4}{*}{ Objects } & Carrying a bag & Above shoulder height \\
\hline & Disturbance & Below hip height \\
\hline & of balance & $\begin{array}{l}\text { Lifting a light object } \\
(<5 \mathrm{~kg})\end{array}$ \\
\hline & & $\begin{array}{l}\text { Lifting a heavy object } \\
(>5 \mathrm{~kg})\end{array}$ \\
\hline \multirow[t]{4}{*}{ Exception } & Aggression & Precision work \\
\hline & $\begin{array}{l}\text { Using hand-held } \\
\text { computer }\end{array}$ & Rubbing/grating \\
\hline & Obstruction & Pick up/put down \\
\hline & Conversation & Pushing/pulling \\
\hline
\end{tabular}


Botje, D., Zoer, I., Ruitenburg, M.M., Frings-Dresen, H.W., Sluiter, J.K. On-site observations of physical work demands of train conductors and service electricians in the Netherlands. Ergonomics: 2010, 53(8), 1016-1023

Appendix B: Definitions of the variables in the task analyses.

\begin{tabular}{|c|c|c|}
\hline Variable & & Definition \\
\hline \multirow[t]{6}{*}{ Task } & Departing the train* & $\begin{array}{l}\text { Ascertain safety sign, whistle for departure, check for clearance, close doors, check } \\
\text { for safety, close own door }\end{array}$ \\
\hline & Service round* & Walk through moving train to assist passengers and answer questions \\
\hline & Checking for valid tickets* & $\begin{array}{l}\text { Walk through moving train to ask passengers for their tickets, to give fines or to } \\
\text { answer passengers' questions }\end{array}$ \\
\hline & Administration* & $\begin{array}{l}\text { While sitting, using the hand-held computer for updates on delays or exceptions, or } \\
\text { processing ticket sales or fines }\end{array}$ \\
\hline & Between tasks* & Time spend on switching between tasks, without knowing what the next task will be \\
\hline & Electrical $^{\dagger}$ Mechanical $^{\dagger}$ & $\begin{array}{l}\text { Electrical maintenance or repair } \\
\text { Mechanical maintenance or repair }\end{array}$ \\
\hline \multirow[t]{9}{*}{ Activity } & Climbing a flight of stairs & $\begin{array}{l}\text { Staircases consisting of three steps or more, where one's arms can be used for } \\
\text { support }\end{array}$ \\
\hline & Opening a door* & Door is slid laterally or pushed/pulled forward/backward \\
\hline & $\begin{array}{l}\text { Checking a } \\
\text { passenger's ticket* }\end{array}$ & $\begin{array}{l}\text { In a moving train, while standing, the employee receives a ticket from a passenger, } \\
\text { looks at it (with cervical flexion) and returns it (every checked passengers counts } \\
\text { as one) }\end{array}$ \\
\hline & Standing & Employee stands or takes a maximum of two steps \\
\hline & Sitting & Employee supports his/her weight with his/her buttocks \\
\hline & Walking & Employee takes three steps or more in a row \\
\hline & Climbing/scrambling ${ }^{\dagger}$ & $\begin{array}{l}\text { Employee moves in a horizontal, vertical, or diagonal direction over an object that } \\
\text { is not made to be moved on (wheelbase, power connector on the roof of the } \\
\text { train) while using arms for support }\end{array}$ \\
\hline & Kneeling/squatting ${ }^{\dagger}$ & $\begin{array}{l}\text { Employee kneels with one or both knees on the ground or squats (feet underneath } \\
\text { body, with knee angle of less than } 90^{\circ} \text { ) }\end{array}$ \\
\hline & Changing brake blocks ${ }^{\dagger}$ & $\begin{array}{l}\text { While standing, the employee uses tools to release the clench, pulls out four to six } \\
\text { brake blocks, puts them down, picks up new ones and pushes them into the } \\
\text { clench and closes it, while assuming cervical and/or thoracic flexion (all of these } \\
\text { aspects could be executed for two wheels at the same time) }\end{array}$ \\
\hline \multirow[t]{6}{*}{ Body posture } & Cervical flexion & $\begin{array}{l}\text { Flexion of } 45^{\circ} \text { in cervical spine, measured by angle of plane through forehead with } \\
\text { sagittal plane }\end{array}$ \\
\hline & Cervical rotation & $\begin{array}{l}\text { Rotation of } 45^{\circ} \text { in cervical spine, measured by angle of plane through forehead } \\
\text { with sagittal plane }\end{array}$ \\
\hline & Lumbar flexion & $\begin{array}{l}\text { Flexion of lumbar and thoracic spine of more than } 45^{\circ} \text {, measured by angle of } \\
\text { longitudinal axis of the thorax with longitudinal axis in sagittal plane }\end{array}$ \\
\hline & Lumbar rotation & $\begin{array}{l}\text { Flexion of lumbar and thoracic spine of more than } 45^{\circ} \text {, measured by angle of } \\
\text { transverse axis through shoulders with global frontal plane }\end{array}$ \\
\hline & Asymmetrical posture $^{\dagger}$ & $\begin{array}{l}\text { Extreme posture that cannot be defined by the above-mentioned body postures } \\
\text { alone (mostly a combination of them) and is thus considered an awkward } \\
\text { posture }\end{array}$ \\
\hline & Reaching* & $\begin{array}{l}\text { Activity beyond arm's length, with an angle of } 60^{\circ} \text { or more in shoulder relative to } \\
\text { thorax }\end{array}$ \\
\hline \multirow[t]{6}{*}{ Objects } & Bag* & Bag carried on the back or over the shoulder \\
\hline & $\begin{array}{l}\text { Disturbance of } \\
\text { body balance* }\end{array}$ & $\begin{array}{l}\text { Lateral movement of the train caused by train switching tracks or by bad quality of } \\
\text { the tracks, resulting in disturbance of the balance of the employee, who needs } \\
\text { support to prevent falling }\end{array}$ \\
\hline & Above shoulder height ${ }^{\dagger}$ & $\begin{array}{l}\text { Manipulating with hands above shoulder height, with shoulder angle being } 60^{\circ} \text { or } \\
\text { more }\end{array}$ \\
\hline & Below hip height ${ }^{\dagger}$ & $\begin{array}{l}\text { Manipulating with hands below hip height, with flexion of thoracic and lumbar } \\
\text { spine }\end{array}$ \\
\hline & Light object $(<5 \mathrm{~kg})^{\dagger}$ & Object weighing less than $5 \mathrm{~kg}$ \\
\hline & Heavy object $(\geq 5 \mathrm{~kg})^{\dagger}$ & Object weighing $5 \mathrm{~kg}$ or more \\
\hline \multirow[t]{9}{*}{ Exception } & Aggression* & $\begin{array}{l}\text { Passenger or colleague shows aggression verbally or physically, using a raised voice } \\
\text { or offensive language }\end{array}$ \\
\hline & Using hand-held computer* & Activity close to body of employee, involving cervical flexion \\
\hline & Obstruction* & Objects or persons limiting the mobility of the employee \\
\hline & Conversation* ${ }^{\dagger}$ & Talking, where during checking for valid tickets it starts only after $30 \mathrm{~s}$ \\
\hline & Precision work ${ }^{\dagger}$ & Precision work, using small tools, or twisting and pushing knobs, pouring oil, etc. \\
\hline & Reaching $^{\dagger}$ & $\begin{array}{l}\text { Activity beyond arm's length, with an angle of } 60^{\circ} \text { or more in the shoulder in } \\
\text { relation to the thorax }\end{array}$ \\
\hline & Rubbing/grating ${ }^{\dagger}$, & Cleaning parts by moving hand/arm forward and backward or up and down \\
\hline & & $\begin{array}{l}\text { Grabbing an object and putting it down (in combination with walking as carrying, } \\
\text { in combination with standing as lifting) }\end{array}$ \\
\hline & Pushing/ pulling ${ }^{\dagger}$ & Applying a horizontal force to an object with one or two hand(s) \\
\hline
\end{tabular}

*Applicable for train conductors only.

${ }^{\dagger}$ A pplicable for service electricians only. 